\title{
PENGEMBANGAN PERTANIAN PERKOTAAN JENIS DAN PENGELOLAANNYA (REVIEW ARTIKEL)
}

\author{
Haryuni $^{1}$, Sapto Priyadi ${ }^{1}$, Suswadi $^{1}$, Mrihrahayu Rumaningsih ${ }^{1}$, Achmad Fatchul Aziez ${ }^{1}$
}

${ }^{1}$ Universitas Tunas Pembangunan Surakarta, Indonesia

\begin{tabular}{|c|c|}
\hline Keyword & Abstrac \\
\hline $\begin{array}{l}\text { Urban Farming, } \\
\text { Verticulture, } \\
\text { Pests, Diseases }\end{array}$ & $\begin{array}{l}\text { The development of science and technology is currently being } \\
\text { followed by changes of the agricultural cultivation system in urban } \\
\text { areas, the system is better known as urban farming or green } \\
\text { community. The development of urban agriculture is very fast, } \\
\text { especially in developing countries and useful for converting narrow }\end{array}$ \\
\hline Corresponding Author & $\begin{array}{l}\text { land around the residence into productive land for farming, meeting } \\
\text { family needs, increasing family income and adding to the beautiful }\end{array}$ \\
\hline $\begin{array}{l}\text { Haryuni } \\
\text { Universitas Tunas } \\
\text { Pembangunan Surakarta } \\
\text { Indonesia } \\
\text { haryuni@lecture.utp.ac.id }\end{array}$ & $\begin{array}{l}\text { environment around the house. The purpose of developing urban } \\
\text { agriculture types and their management is to be able to determine } \\
\text { the specified species and their management so as to provide optimal } \\
\text { results. Data on the type and management used a literature review } \\
\text { of several published articles. The results of a review of several } \\
\text { articles can be concluded that the type of urban agriculture that is } \\
\text { widely developed by the community is verticulture because it can } \\
\text { adjust the land owned, while plant management is carried out in a } \\
\text { planned and regular manner by utilizing household waste for } \\
\text { fertilization and control. Plant disturbances are caused by plant- } \\
\text { disturbing organisms (OPT) consisting of pests (insects) and } \\
\text { diseases (fungi, bacteria, and viruses). }\end{array}$ \\
\hline
\end{tabular}

\begin{abstract}
Abstrak
Perkembangan ilmu dan teknologi saat ini diikuti dengan perubahan sistem budidaya pertanian di perkotaan, sistem tersebut lebih dikenal dengan urban farming atau green community. Perkembangan pertanian perkotaan sangat cepat terutama di negara berkembang dan bermanfaat mengubah lahan sempit di sekitar tempat tinggal menjadi lahan produktif untuk bertani, memenuhi kebutuhan keluarga, menambah penghasilan keluarga serta menambah asri lingkungan di sekitar rumah. Tujuan pengembangan pertanian perkotaan jenis dan pengelolaannya yaitu dapat menentukan jenis yang ditentukan dan pengelolaannya sehingga memberikan hasil yang optimal. Data tentang jenis dan pengelolaan menggunakan tinjauan pustaka dari beberapa artikel yang telah dipublikasikan. Hasil tinjauan beberapa artikel dapat disimpulkan bahwa jenis pertanian perkotaan yang banyak dikembangkan masyarakat adalah vertikultur karena dapat menyesuaikan lahan yang dimiliki, sedangkan pengelolaan tanaman dilakukan secara terencana dan teratur dengan memanfaatkan limbah rumah tangga untuk pemupukan dan pengendalian. Gangguan tanaman disebabkan oleh organisme pengganggu tanaman (OPT) terdiri dari hama (serangga) dan penyakit (jamur, bakteri, dan virus).
\end{abstract}

Kata kunci: Pertanian- perkotaan, vertikultur, hama, Penyakit 
Pada tahun 1800-1900 terdapat 2 - 4\% dari populasi penduduk dunia tinggal di perkotaan, diperkirakan setelah tahun 2020-2050 mencapai 60-70\% (UNFPA, 2007; CFSC, 2011). Pertanian perkotaan berkembang sangat pesat terutama di negara berkembang yang merupakan rantai industri terdiri dari produksi, proses dan pemasaran makanan dan energi untuk memenuhi kebutuhan konsumen di kota. Rantai kegiatan dilakukan dengan metode using dan re-using yang berasal dari sumber alam dan limbah perkotaan Bailkey 2001 cit Parsudi \& Damaijanto, 2019). Proses pertumbuhan penduduk dan urbanisasi diikuti dengan peningkatan kebutuhan pangan, gizi buruk, kebutuhan tempat tinggal, kemiskinan dan pengangguran. Salah satu peluang untuk mencukupi kecukupan pangan, memperbaiki kesehatan, memperbaiki perekoniam, meningkatkan lapangan kerja dan penghasilan dengan sistem pertanian perkotaan (Orsini et al., 2013).

Berdasarkan Undang-Undang nomor 26 tahun 2007 menjelaskan tentang penataan ruang bahwa ada persyaratan untuk ruang terbuka hijau (RTH) minimal 30\% dari luas wilayah kota merupakan RTH umum/publik, bentuk kegiatan : program taman kota, hutan kota disesuaikan dengan sebaran penduduk dan hierarki pelayanan dengan memperhatikan rencana struktur dan pola ruang.

Undang-Undang Pangan nomor 18 tahun 2012 pasal 60 ayat (1) menyatakan bahwa Pemerintah dan Pemda berkewajiban mewujudkan penganekaragaman konsumsi pangan untuk memenuhi kebutuhan gizi masyarakat dan mendukung hidup sehat, aktif dan produktif, ayat (2) tertulis bahwa penganekaragaman konsumsi pangan sebagaimana dimaksud pada ayat (1) diarahkan untuk meningkatkan kesadaran masyarakat dan membudayakan pola konsumsi pangan yang beragam, bergizi seimbang dan aman (B2SA) serta sesuai dengan potensi dan kearifan lokal.

Peraturan Pemerintah momor 17 tahun 2015 memuat tentang ketahanan pangan dan gizi pada pasal 26 menyatakan tentang upaya penganekaragaman pangan salah satunya dilakukan melalui optimalisasi pangan lokal dan lahan pekarangan. Kegiatan pertanian perkotaan dapat dikembangkan pada skala rumah tangga atau masyarakat, hasil pertanian perkotaan beragam yaitu perikanan, peternakan (unggas), tanaman pangan, hortikultura (sayur, buah, dan tanaman hias), rempah-rempah, umbi-umbian dan kacang-kacangan (Ashari dan Saptana, 2012; Orsini et al., 2013). Pengembangan pertanian perkotaan pada skala rumah tangga mampu menopang kebutuhan pangan sehari-hari dan mengurangi pengeluaran di dalam keluarga, selain itu juga memanfaatkan limbah rumah tangga untuk diolah menjadi pestisida hayati dan pupuk organik.

\section{JENIS-JENIS BUDIDAYA PERTANIAN PERKOTAAN}

Jenis pertanian perkotaan yang dikembangkan masyarakat untuk skala rumah tangga tergantung dari luas lahan dan pencahayaan sinar matahari yaitu

1. Vertikultur adalah pola bercocok tanam yang menggunakan wadah tanam vertikal untuk mengatasi keterbatasan lahan, menggunakan media tanah, 


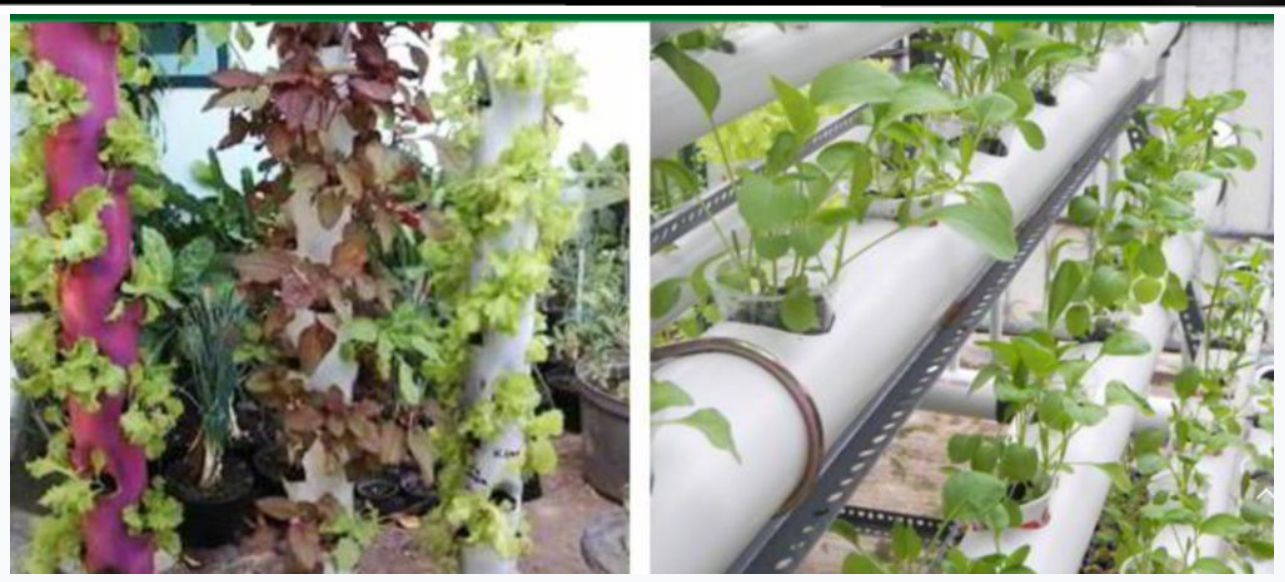

Gambar 1. Sistem Vertikultur

Sumber: Rini Pujiarti, 2019 (www.litbang.pertanian.go.id)

2. Hidroponik adalah suatu metode bercocok tanam tanpa menggunakan media tanah, melainkan dengan menggunakan larutan mineral bernutrisi atau bahan lainnya yang mengandung unsur hara seperti sabut kelapa, serat mineral, pasir, pecahan batu bata, serbuk kayu sebagai pengganti media tanah,

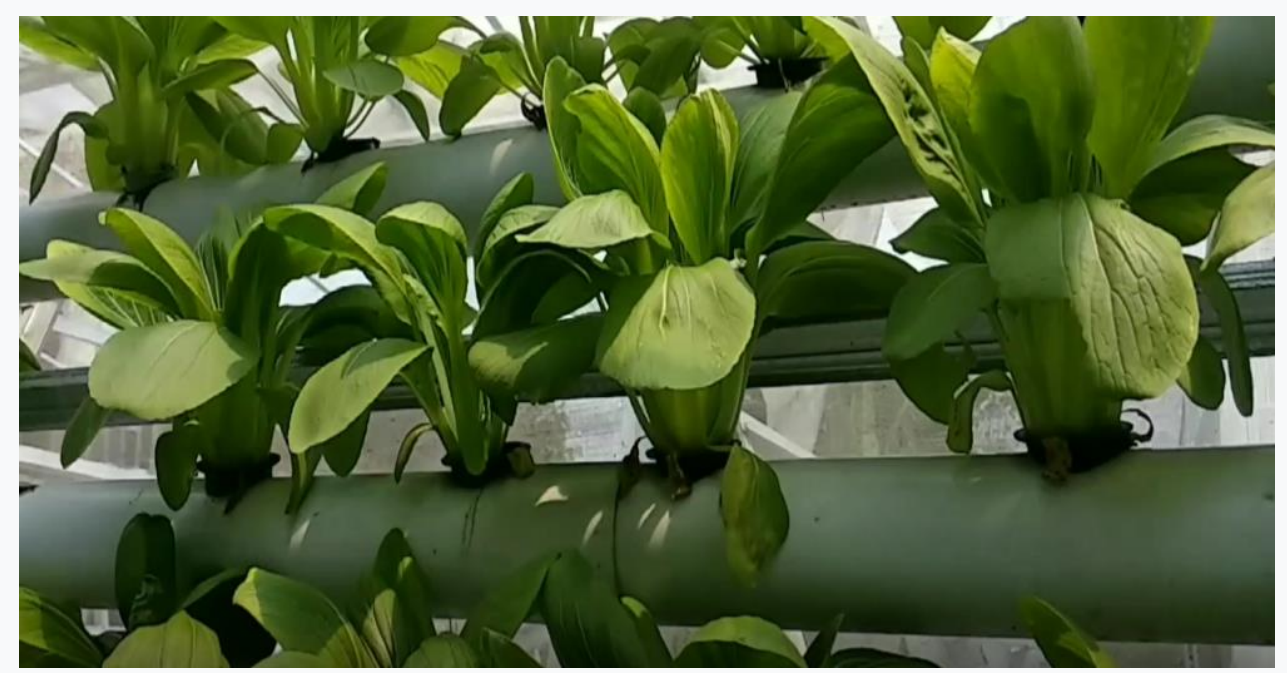

Gambar 2. Sistem Hidroponik

Sumber: Koleksi Fahmi., dkk, 2019

3. Aquaponik adalah kombinasi antara Akuakultur dan Hidroponik yang mampu mendaur ulang nutrisi, dengan menggunakan sebagian kecil air daur ulang hingga memungkinkan pertumbuhan, budidaya ikannya dapat menghemat penggunaan air sampai 97\% (Ecolife Foundation, 2011). Menurut Siswandi dan Sarwono (2013) aquaponik merupakan alternatif pemanfaatan lahan sempit. Diperkuat dengan pernyataan dari Zidni et al., (2013) bahwa aquaponik dapat menghemat lahan, air, dan merupakan sistem budidaya ramah lingkungan, karena memanfaatkan nutrisi yang berasal dari sisa pakan dan limbah metabolism ikan sebagai pupuk tanaman.

Dauhan dkk (2014); Saprianto dan Susiana (2014) menjelaskan hal-hal penting dalam budidaya aquaponik yaitu:

a. Kualitas air dipengaruhi oleh kandungan oksigen, keasaman air $(\mathrm{pH})$, nutrisi terlarut seperti suhu, kadar asam $(\mathrm{pH})$, kandungan oksigen terlarut, nitrit, dan amonia yang menjadi faktor penting dalam budidaya ikan. 
b. Rasio antara jumlah tanaman dan kepadatan ikan, kotoran ikan dimanfaatkan sebagai pupuk bagi tanaman sehingga harus sesuai.

c. Rutinitas pengecekan terhadap sirkulasi air sebagai tindakan antisipasi terjadinya kebocoran.

\section{Manfaat Aquaponik}

Fatmawati (2013) menyatakan beberapa manfaat dari budidaya dengan sistem aquaponik antara lain adalah :

a. Kotoran ikan dapat dimanfaatkan sebagai sumber pupuk organik yang baik bagi pertumbuhan tanaman.

b. Produk yang dihasilkan merupakan produk organik karena hanya menggunakan pupuk dari kotoran ikan yang telah melalui proses biologis.

c. Menghasilkan dua produk sekaligus; yaitu sayur dan ikan, dari satu unit produksi.

d. Dapat menghasilkan sayuran segar dan ikan sebagai sumber protein pada daerahdaerah kering dan ketersediaan lahan terbatas.

e. Bersifat berkelanjutan dengan perpaduan tanaman dan ikan dan siklus nutrien.

f. Selain untuk aplikasi komersial, aquaponik telah menjadi tempat pembelajaran yang populer bagi masyarakat maupun siswa-siswa kejuruan perikanan tentang biosistem terpadu.

g. Populasi tanaman organik yang dapat ditanam 10 kali lipat lebih banyak. Dengan aquaponik tanaman dapat ditanam dengan kerapatan tinggi dengan sistem terapung di atas air. Sistem ini mampu menampung hingga 10 kali lipat jumlah tanaman pada luasan yang sama. Dan setiap akar tanaman selalu mendapat pasokan air yang kaya akan zat hara.

h. Pemeliharaan yang mudah, tidak memerlukan penyiangan, terbebas dari hama tanah dan tidak memerlukan penyiraman.

i. Bila pertumbuhannya baik, tanaman akan tumbuh lebih cepat.

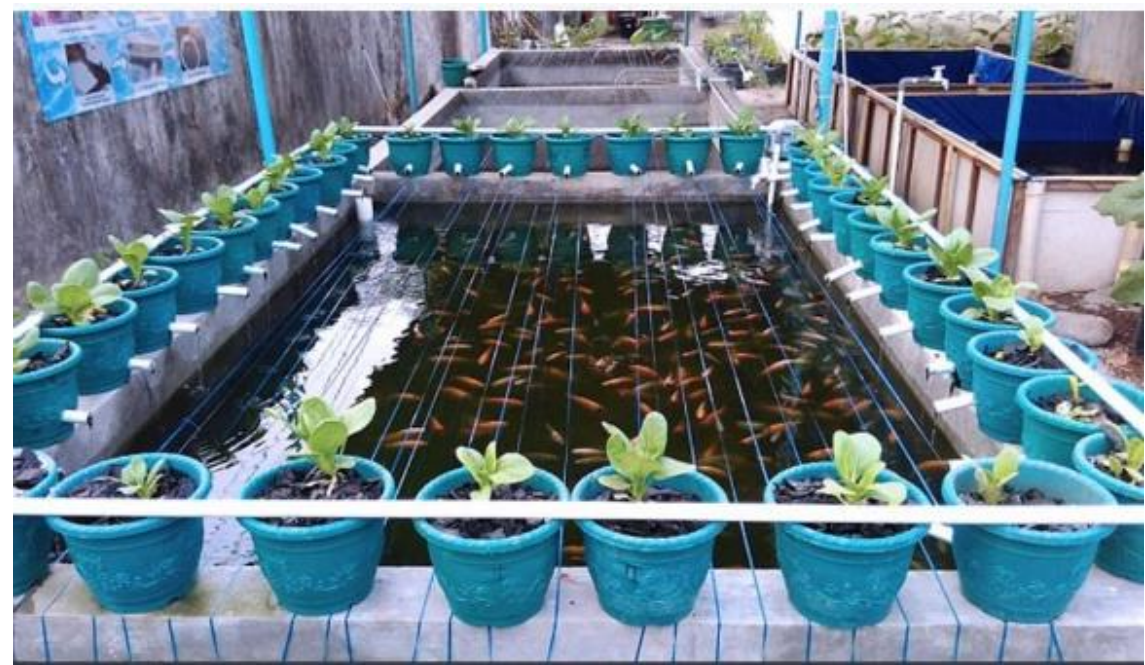

Gambar 3: Sistem Aquaponik

Sumber: Koleksi SMK Negeri H. Moenadi Ungaran Jawa Tengah (2018)

4. Tabulampot (tanaman buah dalam pot),

Anonim, (2019) menjelaskan bahwa penting dan harus diperhatikan dalam budidaya tabulanpot yaitu:

a. Pemilihan bbibit yang sehat, bebas hama penyakit dan cepat berbuah 
b. Wadah/tempat/pot, besar-kecilnya wadah/tempat/pot disesuaikan jenis tanaman yang dibudidayakan sehingga mendapatkan cukup nutrisi untuk pertumbuhan dan perkembangan.

c. Media, campuran media yang baik akan mendukung tanaman cepat berbuah, sebaiknya di bagian dasar wadah diberi arang sekam/batuan, di atasnya dilapisi dengan sabut kelapa.

d. Lokasi, atau tempat sebaiknya selalu terkena cahaya matahari langsung supaya tanaman tidak lembab untuk menghindari serangan hama penyakit.

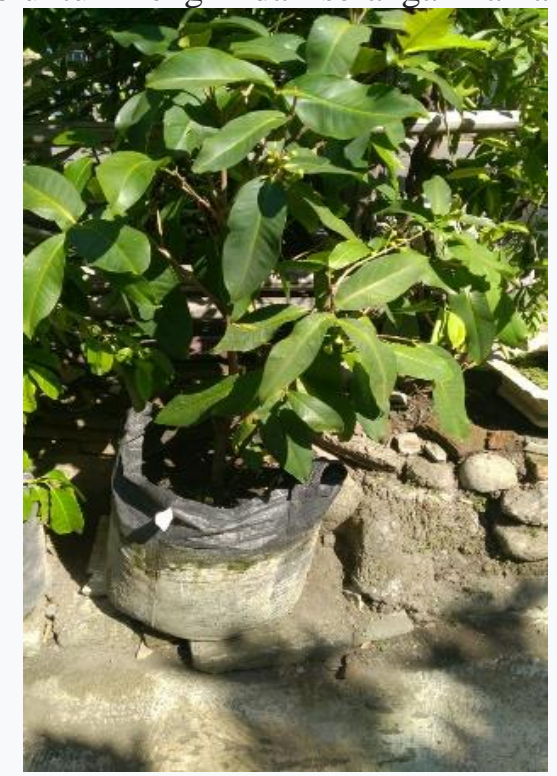

Gambar 4: Sistem Tabulanpot

Sumber: Koleksi pribadi 2021

5. Budidaya tanaman hias, tamanisasi, tanaman toga.

Tanaman hias yang dibudidayakan dapat dikelompokkan menjadi:

a. Bunga, tanaman yang menghasilkan bunga, wangi dan indah.

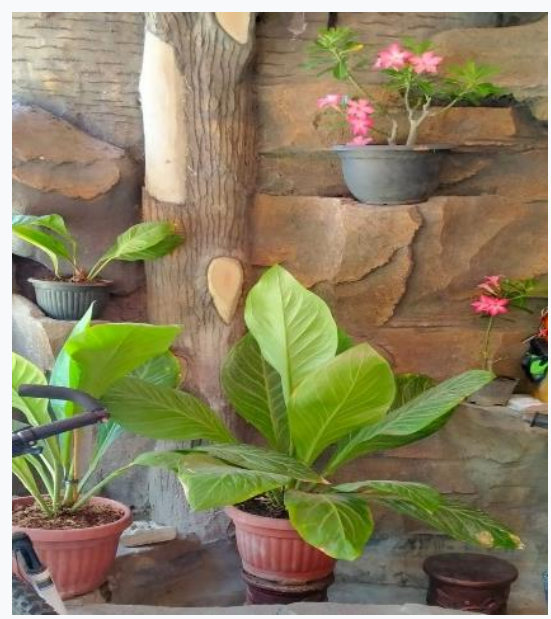

Gambar 5: Budidaya Tanaman Hias

Sumber: Koleksi pribadi (2021)

b. Daun, tanaman yang hanya terdiri dari daun tetapi terlihat indah dan segar, membutuhkan keadaan lingkungan yang lembab. 


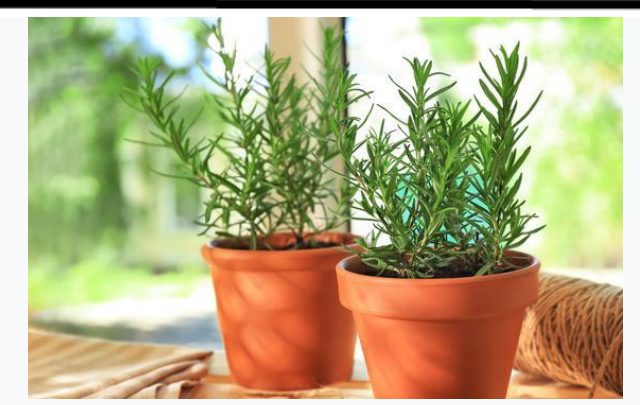

Gambar 6: Tanaman yang terdiri dar daun

Sumber: liputan6.com

c. Akar, mempunyai akar yang menarik atau tanaman yang dibentuk supaya bagian akarnya terlihat dan indah (bonsai).

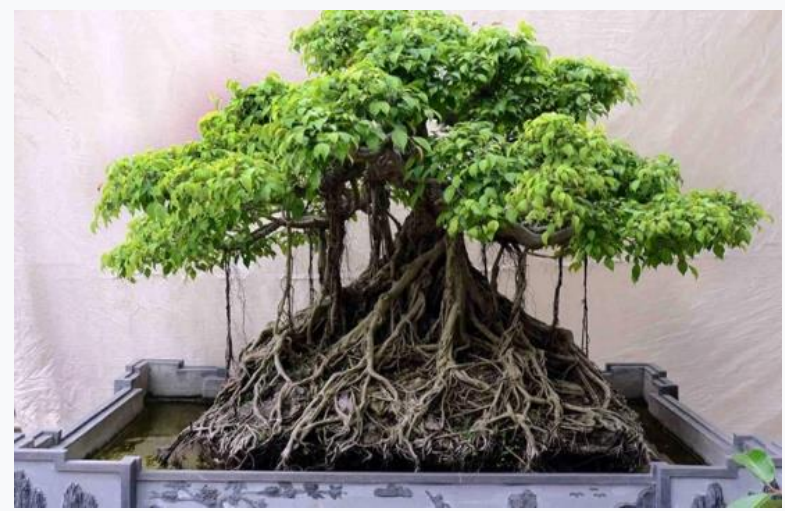

Gambar 7: Tanaman yang memperlihatkan bagian akarnya

Sumber: Sumber rumah.com

Tamanisasi adalah mengubah sebagian lahan sempit ditanami dengan beberapa jenis tanaman di dalam pot terdiri dari tanaman hias, bunga, dan buah, bahkan tanaman toga sehingga terlihat indah, asri dan segar.

Tanaman Toga (Tanaman Obat Keluarga) bisa ditanam di lahan sempit di dalam pot, tanaman toga bias berasal dari tanaman bunga (lavender), tanaman buah (jambu biji, anggur, jeruk nipis/lemon), tanaman rimpang/rempah-rempah (jahe, kunyit, kencur dll), tanaman sayur (kenikir, kemangi, papaya, dll) (Mindarti dan Nurbaetu, 2015)

\section{Peternakan lahan sempit}

Beberapa jenis binatang dapat diternakkan di lahan sempit sehingga menopang keuangan dan konsumsi daging untuk keluarga, antara lain yaitu:

a. Burung, selain suaranya yang merdu juga bulunya indah

b. Unggas (ayam, itik, bebek), bisa digunakan untuk menu keluarga 


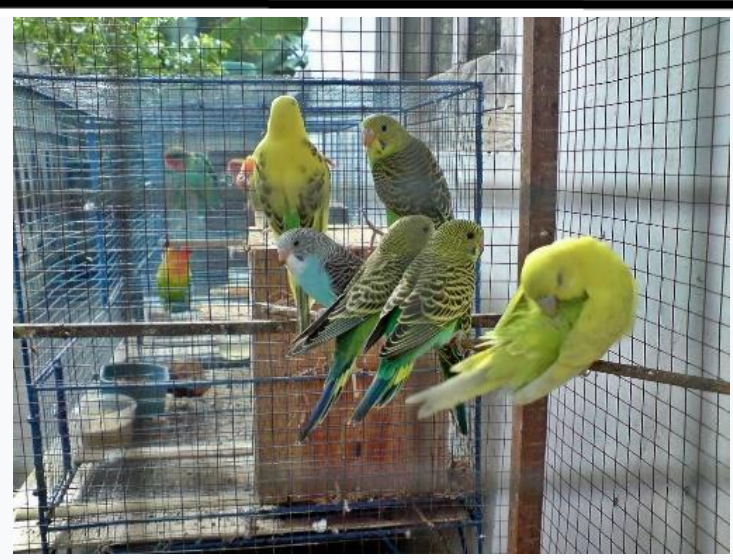

Gambar 8: Ternak burung di lahan sempit

Sumber: Agrowindo (online Google, 2021)

c. Ikan, ikan hias dan ikan air tawar.

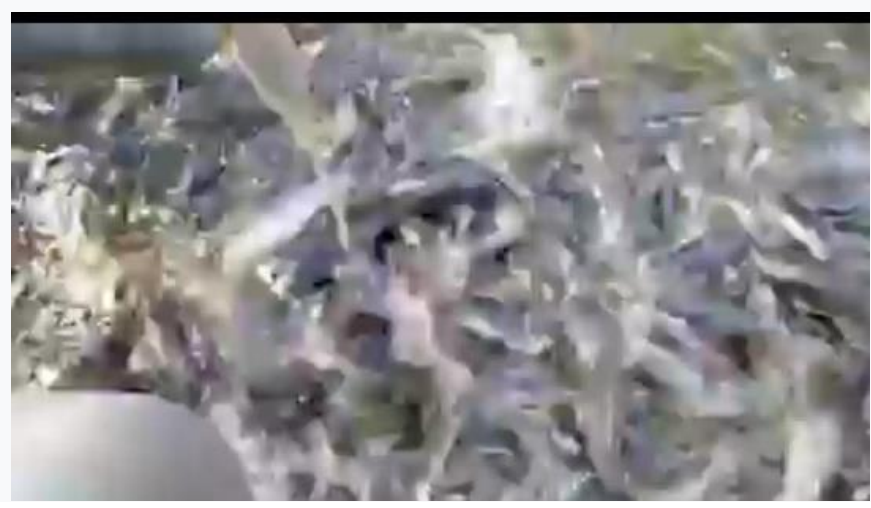

Gambar 9: Ternak lele di lahan sempit

Sumber: Koleksi SMK Negeri H. Moenadi Ungaran Jawa Tengah (2018)

d. Kelinci, dagingnya digunakan untuk dikonsumsi keluarga.

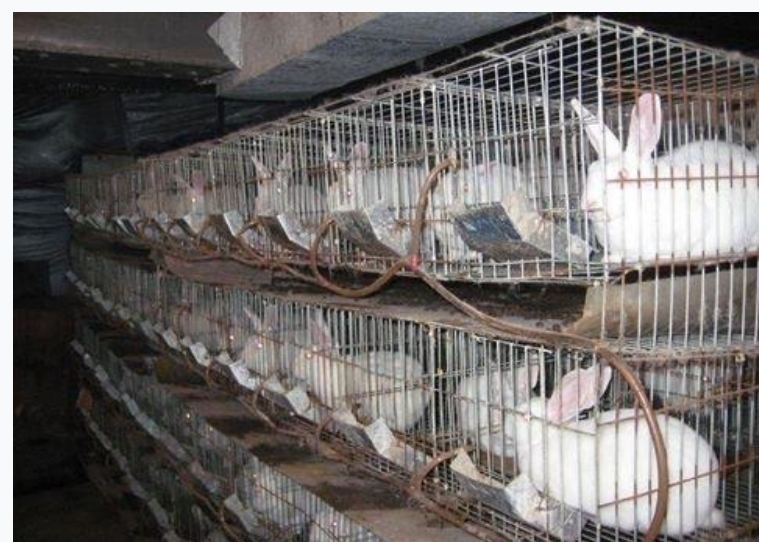

Gambar 10: Ternak kelinci di lahan sempit

Sumber: Siapa bisnis.com (Google, 2021) 
Bahan-bahan yang dihasilkan pertanian kota: sayur-mayur, ikan, berbagai jenis unggas, bunga-bunga, tanaman obat-obatan, buah-buahan, dan berbagai bentuk umbiumbian dan kacang-kacangan

\section{PENGELOLAAN BUDIDAYA PERTANIAN PERKOTAAN}

Pertanian perkotaan berperan sebagai tanaman produktif sehingga menjadi penyedia oksigen, penangkal polusi udara dan memperbaiki kondisi tanah. Dijelaskan oleh Paeru dan Dewi (2015), bahwa selain dalam budidaya pertanian perlu dilakukan pengelolaan yang terdiri dari:

a. Penyiraman

Apabila tanaman diletakkan di tempat yang lembab dan terlindungi dari sinar matahari penyiraman dilakukan seriap hari pagi atau sore dengan melihat keadaan tanah, tetapi kalau keadaan lingkungan tidak lembab penyiraman dapat dilakukan pagi dan sore.

b. Pemupukan

Tanaman membutuhkan nutrisi untuk pertumbuhan, perkembangan dan hasil, pemupukan dan jenis pupuk yang tepat baik pupuk organik maupun an-organik akan memberikan hasil yang baik.

c. Pengendalian hama, penyakit (organisme pengganggu tanaman/OPT) dan gulma

Kendala yang dihadapi dalam budidaya adalah serangan organisme pengganggu tanaman (OPT) yang ditemukan pada saat benih, pembenihan, pertumbuhan, panen, dan pasca panen. Serangan OPT terdiri dari hama, penyakit dan gulma tanaman.

Serangan organisme pengganggu tanaman (OPT) dan gulma merupakan kendala yang serius. Identifikasi dan pengelolaan OPT yang terencana dan teratur meningkatkan ketahanan tanaman terhadap OPT dan mempertahankan hasil/panen. Dalam budidaya pertanian perkotaan perlu dilakukan pemantauan secara rutin dan intensif, sebelum tanaman menunjukkan gejala serangan. Pengendalian hayati maupun pestisida kimia dapat dilakukan sebagai tindakan pengelolaan OPT dan gulma..

d. Pemangkasan

Tunas atau ranting yang tumbuh dan tidak beraturan dihilangkan supaya tanaman memberikan hasil yang maksimal.

e. Penggemburan tanah/penggantian media tanam.

Penggemburan dan penggantian media tanam ditujukan untuk memperbaiki struktur tanah, sehingga tanah remah, draenasi dan aerasi lancer.

f. Pengaturan kelembaban tanaman

Budidaya pertanian perkotaan membutuhkan keadaan yang lembab, tidak menyengat dan cukup sinar matari, sehingga mengurangi penguapan air pada tanaman dan tanaman tidak mudah layu.

\section{KESIMPULAN}

Pengembangan pertanian perkotaan merupakan salah satu solusi ketahanan pangan di perkotaan, jenis dan bentuk pengembangan disesuaikan dengan lahan yang dimiliki dan lokasinya. Pengelolaan pertanian perkotaan perlu dilakukan secara taratur dan terencana untuk menghindari serangan organisme pengganggu tanaman, gulma dan kematian sehingga diperoleh hasil yang maksimal. 
REFERENSI

Undang-Undang Republik Ndonesia Nomor 18 Tahun 2012 Tentang Pangan. $83 \mathrm{hlm}$.

Peraturan Pemerintah Republik Indonesia. No. 17 Tahun 2015. Ketahanan Pangan Dan Gizi. $63 \mathrm{hlm}$

Anonim, 2019. Cara Mudah Menanam Tabulapot. https://disperkimta.bulelengkab.go.id.

Ashari, Saptana, Purwantini, T.B. 2012. Potensi dan Prospek Pemanfaatan Lahan Pekarangan Untuk Mendukung Ketahanan Pangan. Forum Penelitian Agro Ekonomi, Volume 30 No.1, Juli 2012: 13-30.

CFSC (2011) http://www.foodsecurity.org/. Accessed 9 Nov 2012

Dauhan RES, Efendi E, Suparmono. 2014. Efektivitas Sistem Akuaponik dalam Mereduksi Konsentrasi Amonia Pada Sistem Budidaya Ikan. Rekayasa dan Teknologi Budidaya Perairan. 3(1):1-6.

Ecolife Foundation. (2011). Introduction to Village Aquaponics. ECOLIFE, 324 State Place, Escondido, CA $92029.25 \mathrm{hlm}$

Fahmi Andrian, Tutur Umu Latifah, Haryuni. 2019. Laporan Mahasiswa Magang Fakultas Pertanian Tahun 2019. $26 \mathrm{hlm}$

Fatmawati, 2018. Sistem Budidaya Aquaponik. https://pertanian.pontianakkota.go.id/

Francesco Orsini, Remi Kahane, Remi Nono-Womdim \& Giorgio Gianquinto, 2013. Urban Agriculture in the Developing World: A Review. Agron. Sustain. Dev. DOI 10.1007/s13593-013-0143-Z.

Irfan Zidni, Iskandar, Achmad Rizal, Yuli Andriani, Rian Ramadan. 2019. Efektivitas Sistem Akuaponik Dengan Jenis Tanaman Yang Berbeda Terhadap Kualitas Air. 9 (1): 81-94

Luthan, P. L. A., Nikman, Y., Hasibuan, H. N., \& Malau, J. P. A. (2019). Pelatihan Urban Farming Sebagai Solusi Ruang Terbuka Hijau Di Lorong Sidodadi Medan Helvetia. Jurnal Pengabdian Kepada Masyarakat, 25(1): 1-5 https://doi.org/10.24114/jpkm.v25i1.13933.

Media Budidaya Ikan. Jurnal Perikanan dan Kelautan 9 (1): 81 - 94.

Paeru, R.H., \& Trias Qurnia Dewi. (2015). Panduan Praktis Bertanam Sayuran di Pekarangan. Jakarta: Penebar Swadaya. $76 \mathrm{hlm}$

Rini Pujiarti, 2019. Budidaya Di Lahan Sempit Dengan Vertikultur. http://cybex.pertanian.go.id/

Saparinto C. \& Susiana R. (2014). Panduan Lengkap Budidaya Ikan dan Sayuran dengan sistem Akuaponik. Lily Publisher. Yogyakarta. 114 hlm

Setyo Parsudi, Damaijanto, 2019. Model, Motivasi Dan Kendala Masyarakat Dalam Melakukan Pertanian Kota (Urban Farming) Di Kota Surabaya. Berkala Ilmiah Agribisnis AGRIDEVINA : Vol. 8 (1): 34-47.

Siswandi dan Sarwono. 2013. Uji Sistem Pemberian Nutrisi dan Macam Media terhadap Pertumbuhan dan Hasil Selada (Latuca sativa L.) Hidroponik. J. Agronomika 8(1): 144-148.

Susi Mindarti dan Bebet Nurbaeti, 2015. Buku Saku. Tanaman Obat Keluarga (TOGA). BALAI Pengkajian Teknologi Pertanian (Bptp) Jawa Barat. Balai Besar Pengkajian Dan Pengembangan Teknologi Pertanian. Badan Penelitian Dan Pengembangan Pertanian. Kementerian Pertanian. $30 \mathrm{hlm}$

UNFPA (2007) State of world population 2007: unleashing the potential of urban growth. United Nations Population Fund (UNFPA). $108 \mathrm{hlm}$ 